\title{
Khả năng ức chế virus gây bệnh Gumboro trên gà 3 tuần tuổi của Interferon Alpha gà
}

\section{The ability inhibition Gumboro disease virus in 3-week-old chickens of chicken Interferon Alpha}

\author{
Nguyễn Thị Thanh Giang ${ }^{*}$, Hồ Quảng Đồ ${ }^{2}$, Nguyễn Đăng Quân ${ }^{1}$ \\ ${ }^{1}$ Trung tâm Công nghệ Sinh học Thành phố Hồ Chí Minh, Việt Nam \\ ${ }^{2}$ Khoa Nông nghiệp, Đại học Cần Thơ, Việt Nam \\ *Tác giả liên hệ, Email: nttgiang84@yahoo.com.vn
}

THÔNG TIN

DOI: $10.46223 / \mathrm{HCMCOUJS.}$ tech.vi.15.1.1017.2020

Ngày nhận: 13/04/2020

Ngày nhận lại: 18/09/2020

Duyệt đăng: 20/10/2020

Tù khóa:

Interferon, Gumboro, gà, rChIFN- $\alpha$
TÓM TẮT 
on yeast pichia pastoris and was functional antivirus. The objective of this study was determined recombinant chicken interferon alpha (rChIFN- $\alpha$ ) effectiveness in 3-week-old chickens infected infectious bursal disease virus (IBDV). In the present study, we used 3-week-old chickens without IBDV antibodies. Each 3-week-old chickens were infected virulent Gumboro disease virus with dose of $5 \times 10^{4}$ ELD $_{50}$. After 24 hours infected virus, they were exposed to eye/nasal drops with one of doses $0.1 \mu \mathrm{g} / \mathrm{chick} ; 1 \mu \mathrm{g} /$ chick; $10 \mu \mathrm{g} /$ chick or $100 \mu \mathrm{g} / \mathrm{chick}$. The results suggested treatment with $\mathrm{rChIFN}-\alpha 0.1 \mu \mathrm{g} / \mathrm{chick}$, the chickens' protected and survival rate were $46.7 \%$ and $80 \%$ respectively. Group of chickens were treated $\mathrm{rChIFN}-\alpha 1 \mu \mathrm{g} /$ chick, the protected and survival rate of chickens respectively $60.0 \%$ and $86.7 \%$; The same result with chickens were treated rChIFN- $\alpha 10 \mu \mathrm{g} /$ chick and $100 \mu \mathrm{g} /$ chick, the chickens' protected and survival rate were $66.7 \%$ and $93.3 \%$, respectively. Meanwhile, the positive control group (chicken infected virus, untreated), unprotected chickens (infection rate was 100\%) and survival rate was only 60,00\%. The negative control (chickens uninfected viruses, untreated with $\mathrm{rChIFN}-\alpha$ ), completely uninfected and $100 \%$ survival chickens. The result suggested that rChIFN- $\alpha$ have effective treating Gumboro disease and depends on the dose used. In addition, the chickens' antibody titres shown

Keywords:

Interferon, Gumboro, chicken, rChIFN- $\alpha$ that the chickens' immune response in $\mathrm{rChIFN}-\alpha$ groups was not different than the chickens infected only Gumboro disease virus, suggested that $\mathrm{rChIFN}-\alpha$ did not affect the chickens' immune response.

\section{Giới thiệu}

Trên gia cầm, bệnh do virus gây ra thường nguy hiểm và ảnh hưởng đến ngành chăn nuôi. Trong đó, bệnh Gumboro là bệnh truyền nhiễm cấp tính nguy hiểm, chủ yếu diễn ra ở gà và gà tây. Bệnh có đặc điểm gây viêm túi Fabricius, xuất huyết cơ ngực, cơ đùi, làm hoại tử thận và đặc biệt làm suy giảm hệ miễn dịch hoặc làm mất khả năng đáp ứng miễn dịch đối với vaccine phòng các bệnh khác và dễ bị cảm nhiễm các bệnh truyền nhiễm khác (Pham \& Nguyen, 2004). Hiện tại, bệnh Gumboro không có biện pháp điều trị hiệu quả, người chăn nuôi gia cầm chủ yếu dựa vào chế độ chăm sóc và các lịch trình tiêm chủng để phòng ngừa và kiểm soát sự lây lan của căn bệnh này. Interferon alpha gà $(\mathrm{ChIFN}-\alpha)$ là một cytokine có tiềm năng ứng dụng lớn trong công nghiệp chăn nuôi gia cầm. ChIFN- $\alpha$ có đặc tính ức chế sự hoạt động của mRNA dẫn đến ức chế quá trình nhân lên của virus. Do đặc tính đáp ứng không đặc hiệu, ChIFN- $\alpha$ được coi là yếu tố kích hoạt miễn dịch. Ngoài ra ChIFN- $\alpha$ được chú ý vì nó là hợp chất: có phổ hoạt động rộng (tác động lên nhiều loại virus khác nhau trên gia cầm), gần giống với các hợp chất tự nhiên, hiệu quả cao, tiện lợi khi sử dụng. Các gene mã hóa interferon alpha gà tái tổ hợp $(\mathrm{rChIFN}-\alpha)$ đã lần lượt được tạo dòng, biểu hiện, và đều cho hoạt tính sinh học khi thử nghiệm in vitro và cả in vivo (Hou et al., 2011; Li, De-gang, Yong-jun, \& Yi, 2008; Meng et al., 2011). Tuy nhiên, để sản xuất rChIFN- $\alpha$ với số lượng lớn và giá thành thấp phù hợp cho chăn nuôi thì phải cân nhắc các hệ thống biểu hiện. Trong số đó, nấm men pichia pastoris là một ứng viên đầy tiềm năng, nó đã được sử dụng để biểu hiện IFN- $\alpha$ của nhiều loài như heo (Yu et al., 2010), bò (Iglesias-Figueroa et al., 2016), trâu (Tyagi 
et al., 2017), lạc đà (Wang, Wang, Li, Guo, \& Liu, 2015), người (Ghosalkar, Sahai, \& Srivastava, 2008; Sams et al., 2017) với sản lượng cao, và IFN- $\alpha$ có hoạt tính sinh học tốt. Ngoài ra, pichia pastoris có thể biểu hiện protein với hàm lượng từ miligram tới gram cả trong nghiên cứu phòng thí nghiệm lẫn trong sản xuất quy mô công nghiệp (Macauley-Patrick, Fazenda, McNeil, \& Harvey, 2005) và thành phần môi trường nuôi cấy đơn giản, chi phí lên men thấp, các phương pháp sử dụng được thương mại hóa, chủng và các vector biểu hiện có sẵn trên thị trường (Invitrogen) (Zhang, Inan, \& Meagher, 2000). Do vậy, có thể thấy, pichia pastoris là ứng viên biểu hiện protein tiềm năng nhất hiện nay. Trung tâm Công nghệ Sinh học Thành phố Hồ Chí Minh đã nghiên cứu tạo ra rChIFN- $\alpha$ biểu hiện trên hệ thống tế bào nấm men pichia pastoris (Vo, Nguyen, Nguyen, \& Nguyen, 2014). Do vậy chúng tôi tiến hành nghiên cứu khả năng ức chế virus gây bệnh Gumboro trên gà 3 tuần tuổi nhằm, làm cơ sở tiến hành các nghiên cứu đánh giá hoạt tính kháng nhiều loại virus khác gây bệnh trên gia cầm.

\section{Vật liệu và phương pháp}

\subsection{Nguyên vật liệu}

Gà giống Tam Hoàng 1 ngày tuổi được nuôi lớn đến 3 tuần tuổi. Gà được kiểm tra kháng thể thụ động kháng virus Gumboro, dựa trên khả năng hình thành kết tủa giữa kháng thể trong máu gà thí nghiệm và kháng nguyên - virus Gumboro trong vaccine, khi đạt 3 tuần tuổi. Tất cả gà cho kết quả âm tính khi thực hiện phản ứng kết tủa khuếch tán trên thạch (AGP-Agarose Gel Precipitation) sẽ được sử dụng làm thí nghiệm.

Virus Gumboro độc lực cao (bộ môn Thú y, Khoa Nông nghiệp và Sinh học Ú̉ng dụng, Đại học Cần Thơ).

Dịch rChIFN_a (Trung tâm Công nghệ Sinh học Thành phố Hồ Chí Minh).

Kháng nguyên và kháng thể chuẩn kháng virus Gumboro (CSIRO, Australia).

Bộ kit FlockCheck IBD-XR (IDEXX Laboratories, USA).

Agarose và các sinh phẩm cần thiết dùng trong phản ứng AGP.

Trứng gà có phôi 10 ngày tuổi không có kháng thể kháng Gumboro (dùng thí nghiệm tính liều gây chết $50 \%$ phôi -ELD 50 : embryo lethal dose $50 \%$ ).

\subsection{Phuơng pháp thí nghiệm}

\subsubsection{Chuẩn bị dịch virus Gumboro và xác định liều $E L D_{50}$}

Virus gây bệnh Gumboro được thu nhận từ các mẫu bệnh phẩm (bộ môn Thú Y, khoa Nông nghiệp Đại học Cần Thơ). Dịch virus này được gây nhiễm trên phôi gà 10 ngày tuổi, với nồng độ theo $\lg$ từ 10-1 đến 10-8, được tiêm vào màng nhung niệu của phôi, mỗi phôi được tiêm $0,1 \mathrm{ml}$ dịch virus và theo dõi sự phát triển phôi sau mỗi 24 giờ tiêm virus cho đến tối đa 140 giờ (5 ngày) sau tiêm. Mỗi khi phôi chết, tiến hành thu dịch niệu và kiểm tra sự hiện diện của virus dựa trên phản ứng khuếch tán trên thạch với kháng thể chuẩn kháng virus Gumboro. Cách tính liều $\mathrm{ELD}_{50}(50 \%$ embryo lethal dose - liều gây chết $50 \%$ phôi thử nghiệm) dựa vào phương pháp của Reed và Muench (1938).

\subsubsection{Xác định độc lục của virus Gumboro trên gà thí nghiệm}

Gà nghiệm thức virus và nhóm đối chứng. Nhóm nghiệm thức virus, mỗi gà được nhỏ mắt/mũi với $0,2 \mathrm{ml}$ dịch virus gumboro chứa $5 \times 10^{4} E L D_{50}$; nhóm đối chứng gà được nhỏ mắt/mũi với $0,2 \mathrm{ml}$ dung dịch PBS (phosphate buffered saline). Sau khi xử lý với virus, gà được theo dõi mỗi ngày, quan sát triệu chứng bệnh, ghi nhận số gà bệnh, chết, và mổ khám gà chết để 
kiểm tra bệnh tích. Thí nghiệm được thực hiện lặp lại 03 lần (tổng số 15 gà/ nghiệm thức). Sau 07 ngày lây nhiễm virus, những gà sống được thu huyết thanh để thực hiện phản ứng kết tủa khuếch tán trong thạch (agar gel precipitation, APG). Tất cả các gà trong thí nghiệm được chăm sóc trong cùng điều kiện). Lưu ý, gà thí nghiệm ở mỗi lô được nuôi cách biệt tránh sự lây nhiễm giữa gà ở nghiệm thức đối chứng và nghiệm thức gây nhiễm virus.

\subsubsection{Xác định khả năng kháng virus Gumboro của rChIFN- $\alpha$ trong điều kiện in vivo}

Gà 3 tuần tuổi, không có kháng thể kháng Gumboro, được chia làm 6 nhóm ngẫu nhiên, tổng gà 03 lần thí nghiệm ở mỗi nhóm là 30 con (Bảng 1). Các nhóm thí nghiệm gồm: 04 nhóm điều trị sử dụng rChIFN- $\alpha$ với các nồng độ $0,1 \mu \mathrm{g} / \mathrm{con}, 1 \mu \mathrm{g} / \mathrm{con}, 10 \mu \mathrm{g} / \mathrm{con}$ hoặc $100 \mu \mathrm{g} / \mathrm{con}$; nhóm đối chứng nhiê̂m virus không được điều trị $(\mathrm{DC}(+))$; nhóm đối chứng gà khỏe mạnh, không nhiễm

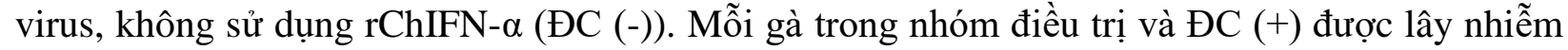
với $0,2 \mathrm{ml}$ dịch virus Gumboro liều $5 \times 10^{4} E L D_{50}$ bằng cách nhỏ mắt/mũi; sau 24 giờ gây nhiễm

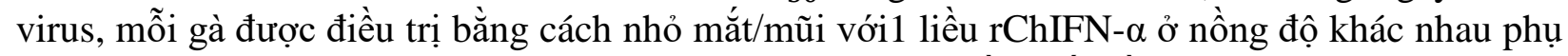
thuộc vào nhóm thí nghiệm. Trong thời gian thí nghiệm 3 tuần (bắt đầu tính từ ngày gà được lây nhiễm virus), ghi nhận số gà bệnh, chết; những gà chết được tiến hành mổ khám, ghi nhận bệnh tích và thu lấy mẫu bệnh phẩm (túi Fabricius, tuyến ức, lách, gan) để kiểm tra virus Gumboro. Gà được lấy máu ở mỗi đầu tuần thí nghiệm để kiểm tra hiệu giá kháng thể.

\section{Bảng 1}

Bố trí thử nghiệm xác định hiệu quả của rChIFN- $\alpha$ trong điều trị bệnh Gumboro

\begin{tabular}{|c|c|c|c|c|c|}
\hline STT & Số lưọng & Nhóm & Số liều & Virus & Đường cấp \\
\hline 1 & 30 & rChIFN- $\alpha 0,1 \mu \mathrm{g} / \mathrm{con}$ & 1 & + & Mắt/ mũi \\
\hline 2 & 30 & rChIFN- $\alpha 1 \mu \mathrm{g} / \mathrm{con}$ & 1 & + & Mắt/ mũi \\
\hline 3 & 30 & rChIFN- $\alpha 10 \mu \mathrm{g} / \mathrm{con}$ & 1 & + & Mắt/ mũi \\
\hline 4 & 30 & rChIFN- $\alpha 100 \mu \mathrm{g} / \mathrm{con}$ & 1 & + & Mắt/ mũi \\
\hline 5 & 30 & Đối chứng virus $(\mathbf{Đ C}(+))$ & $-/ \mathrm{PBS}$ & + & Mắt/ mũi \\
\hline 6 & 30 & Đối chứng không tác động (ĐC(-)) & $-/ \mathrm{PBS}$ & - & Mắt/ mũi \\
\hline
\end{tabular}

Nguồn: Kết quả phân tích dữ liệu của nhóm nghiên cứu

Chỉ tiêu theo dõi:

Tỉ lệ gà được bảo hộ $(\%)=$ [(Số gà thí nghiệm - Số gà bệnh $) /$ Số gà thí nghiệm] x 100

Tỉ lệ gà chết $(\%)=$ (Số gà chết/ Số gà thí nghiệm) x100

Tỉ lệ gà sống $(\%)=100$ - tỉ lệ gà chết

Hiệu giá kháng thể kháng Gumboro: $\log 10$ hiệu giá $=1,09(\log 10 \mathrm{~S} / \mathrm{P})+3,36$ (theo hướng dẫn của bộ kit phát hiện kháng thể kháng Gumboro, kit FlockCheck IBD-XR)

S/P: là tỷ lệ dương tính của mẫu.

Chỉ số $\mathrm{S} / \mathrm{P} \leq 0.2$ tương ứng với kết quả âm tính (mẫu huyết thanh âm không chứa kháng thể kháng Gumboro).

Chỉ số $\mathrm{S} / \mathrm{P}>0,2$ tương ứng với kết quả dương tính (gà đã được tiêm ngừa hoặc đã tiếp xúc với virus Gumboro). 
Hiệu giá kháng thể $\geq 396$ : mẫu huyết thanh dương tính với kháng thể kháng virus Gumboro.

\subsection{Xủ̉ lý thống kê số liệu thục nghiệm}

Tỉ lệ gà bệnh, tỉ lệ gà chết, tỉ lệ bảo hộ, tỉ lệ gà sống và hiệu giá kháng thể được xử lý bằng phép thử Chi - Square test trong chương trình stagraphic Centurion XV.

\section{Kết quả và thảo luận}

\subsection{Chuẩn bị dịch virus Gumboro và xác định liều $E L D_{50}$}

Sau mỗi 24 giờ tiêm dịch virus, soi kiểm tra phôi, các trứng có phôi chết được thu dịch niệu và biểu hiện của phôi chết được ghi nhận. Kết quả cho thấy, toàn bộ các phôi chết sau khi tiêm dịch virus đều có các biểu hiện như: phôi chết xuất huyết da đầu và chân, gan phôi xuất huyết, màng nhung niệu có những điểm xuất huyết. Khi nhiễm virus Gumboro, phôi chết sẽ có những biểu hiện như sung huyết, xuất huyết điểm ở da, bụng căng phồng ứ nước, xuất huyết ở vùng đầu, có những điểm hoại tử nhỏ và xuất huyết ở gan, sung huyết ở phổi, lách nhạt màu (Graaf et al., 2018). Thêm nữa, dịch nước trứng thu từ các phôi chết đều cho kết quả tạo kết tủa khi thực hiện phản ứng AGP. Điều này chứng tỏ dịch virus Gumboro gây bệnh chết phôi với các bệnh tích điển hình.

Sau 5 ngày tiêm phôi, kết quả cho thấy nồng độ virus thấp nhất cho tỉ lệ phôi chết trên $50 \%$ và nồng độ virus cao nhất cho tỉ lệ phôi chết dưới $50 \%$ lần lượt là $10^{-4}$ và $10^{-5}$, với tỉ lệ phôi chết tương ứng $70 \%$ và $44 \%$. Dựa trên công thức của Reed và Muench (1938) tính được liều ELD $_{50 \%} / 0,2 \mathrm{ml}$ là $10^{4,77}$, có nghĩa $0,2 \mathrm{ml}$ dịch virus ban đầu chứa $10^{4,77}$ liều gây chết $50 \%$ phôi.

\section{2. Độc lục của virus Gumboro trên gà thí nghiệm}

Sau 07 ngày thí nghiệm, kết quả ghi nhận tất cả gà (15 con) ở nhóm đối chứng đều khỏe mạnh, không có gà bệnh và không có gà chết. Các mẫu huyết thanh thu ở nhóm nghiệm thức này đều cho kết quả $100 \%$ không tạo kết tủa khi thực hiện phản ứng AGP. Ở nhóm virus, 100\% gà trong nhóm đều biểu hiện bệnh sau ngày thứ 3-6 nhiễm virus; đồng thời $100 \%$ mẫu huyết thanh ở gà còn sống sau thí nghiệm (8/15) đều tạo kết tủa khi thực hiện phản ứng AGP và tỉ lệ gà chết lên đến 46,7\% (7/15).

Gà nhiễm bệnh có các biểu hiện gà mệt, xù lông, bỏ ăn, thường dồn về một góc; tiêu chảy và phân dính vào hậu môn, phân có màu trắng có niêm dịch, hoặc nhiều nước, đôi khi có lẫn máu; gà tự mổ vào hậu môn, da chân khô, gà nằm phủ phục, bỏ ăn, suy nhược và chết. Gà chết, mổ khám ghi nhận bệnh tích gồm túi fabrucius sưng, xung huyết; xuất huyết cơ đồi, cơ ngực; xuất huyết giữa dạ dày cơ và dạ dày tuyến, thận sưng. Đây là các biểu hiện đặc trưng của bệnh tích do virus Gumboro gây ra (Dey, Pathak, Ramamurthy, Maity, \& Chellappa, 2019; Le, 2004; Teshome, Fentahunand, \& Admassu, 2015). Các kết quả này phù hợp với nhận định của Marcus và Hou, các tác giả cho rằng gà rất cảm mãn với virus ở giai đoạn 3-6 tuần tuổi, tỉ lệ chết có thể 40-60\% (Hou et al., 2011; Marcus, Heide, \& Sekellick, 1999). Điều này khẳng định chủng virus sử dụng trong thí nghiệm là chủng virus Gumboro độc lực cao.

\subsection{Khả năng kháng virus Gumboro của rChIFN-a trên gà 3 tuần tuổi}

Sau khi nhiễm virus, gà thí nghiệm có biểu hiện bệnh và chết sau 3-7 ngày. Khả năng

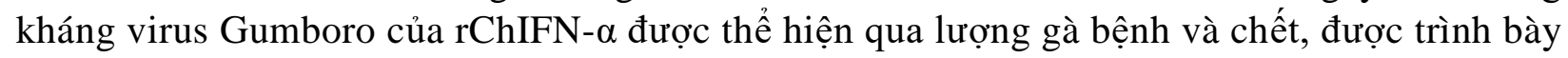
trong Bảng 2. 


\section{Bảng 2}

Tỉ lệ gà sống chết chết sau 7 ngày bị gây nhiễm virus

\begin{tabular}{|c|c|c|c|c|c|c|c|}
\hline \multirow[b]{2}{*}{ Nhóm } & \multirow{2}{*}{$\begin{array}{c}\text { Số } \\
\text { lượng }\end{array}$} & \multicolumn{2}{|c|}{ Gà bệnh } & \multicolumn{2}{|c|}{ Gà chết } & \multicolumn{2}{|c|}{ Gà khỏe/sống } \\
\hline & & $\begin{array}{l}\text { Số lưọng } \\
\text { (con) }\end{array}$ & $\begin{array}{l}\text { Tỉ lệ } \\
(\%)\end{array}$ & $\begin{array}{l}\text { Số lương } \\
\text { (con) }\end{array}$ & Tỉ lệ (\%) & $\begin{array}{c}\text { Tỉ lệ bảo } \\
\text { hộ (\%) }\end{array}$ & $\begin{array}{c}\text { Tỉ lệ sống } \\
(\%)\end{array}$ \\
\hline rChIFN- $\alpha 0,1 \mu \mathrm{g} / \mathrm{con}$ & 30 & 16 & $53,33^{\mathrm{a}}$ & 6 & $20^{\mathrm{a}}$ & $46,67^{\mathrm{a}}$ & $80,0^{\mathrm{a}}$ \\
\hline rChIFN- $\alpha 1 \mu \mathrm{g} / \mathrm{con}$ & 30 & 12 & $40,0^{b}$ & 4 & $13,33^{\mathrm{ab}}$ & $60,0^{b}$ & $86,67^{\mathrm{ab}}$ \\
\hline rChIFN- $\alpha 10 \mu \mathrm{g} / \mathrm{con}$ & 30 & 10 & $33,33^{b}$ & 2 & $6,67^{\mathrm{bc}}$ & $66,67^{\mathrm{b}}$ & $93,33^{b c}$ \\
\hline rChIFN- $\alpha 100 \mu \mathrm{g} / \mathrm{con}$ & 30 & 10 & $33,33^{b}$ & 2 & $6,67^{\mathrm{bc}}$ & $66,67^{\mathrm{b}}$ & $93,33^{b c}$ \\
\hline $\mathrm{ĐC}(+)$ & 30 & 30 & $100^{c}$ & 12 & $40,0^{\mathrm{d}}$ & $0^{c}$ & $60,0^{\mathrm{d}}$ \\
\hline $\mathrm{ĐC}(-)$ & 30 & 0 & $0^{\mathrm{d}}$ & 0 & $0^{\mathrm{c}}$ & $100^{\mathrm{d}}$ & $100^{\mathrm{c}}$ \\
\hline
\end{tabular}

Các số trong cùng một cột mang những chữ số mũ khác nhau thì sai khác nhau có ý nghĩa thống kê $(\mathrm{P}<0,05)$

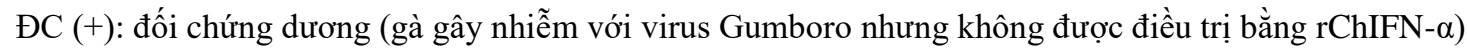

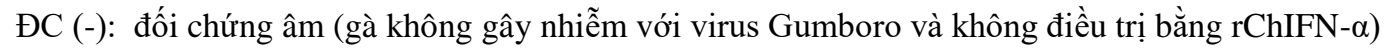

Nguồn: Kết quả xử lý từ dữ liệu điều tra

Kết quả Bảng 2 cho thấy, toàn bộ gà ở nhóm ĐC $(+)$ bị nhiễm bệnh (tỉ lệ bảo hộ $0 \%$ ), và và chết (tỉ lệ chết lên đến $40 \%$ ), đây là nhóm có tỉ lệ bệnh và chết cao nhất, có khác biệt với nhóm ĐC (-) và các nhóm còn lại. Nhóm ĐC (-) gà không bị ảnh hưởng (tỉ lệ bảo hộ đạt 100\%). Trong

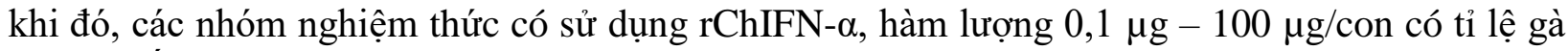
bệnh, chết và tỉ lệ bảo hộ dao động tương ứng là 33,33\% - 53,33\%; 6,67\% - 20\% và 46,67\% $66,67 \%$, các tỉ lệ này phụ thuộc nồng độ rChIFN- $\alpha$ sử dụng.

Trong các nhóm sử dụng $\mathrm{rChIFN-} \alpha$, kết quả ghi nhận cụ thể: nhóm sử dụng $\mathrm{rChIFN- \alpha} 0,1$ $\mu \mathrm{g} /$ con có tỉ lệ gà bệnh, chết tương ứng $53,33 \%$ và $20 \%$, tỉ lệ này là cao nhất so với các nhóm còn

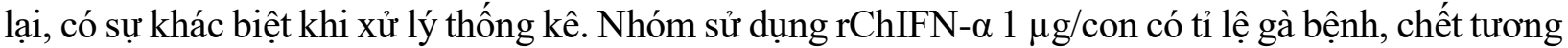
ứng $40,0 \%$ và $13,33 \%$. Hai nhóm sử dụng $\mathrm{rChIFN}-\alpha 10 \mu \mathrm{g} / \mathrm{con}$ và $100 \mu \mathrm{g} / \mathrm{con}$ có kết quả điều trị giống nhau, tỉ lệ gà bệnh và chết tương ứng $33,33 \%$ và $6,67 \%$, thấp nhất so với các nhóm còn lại.

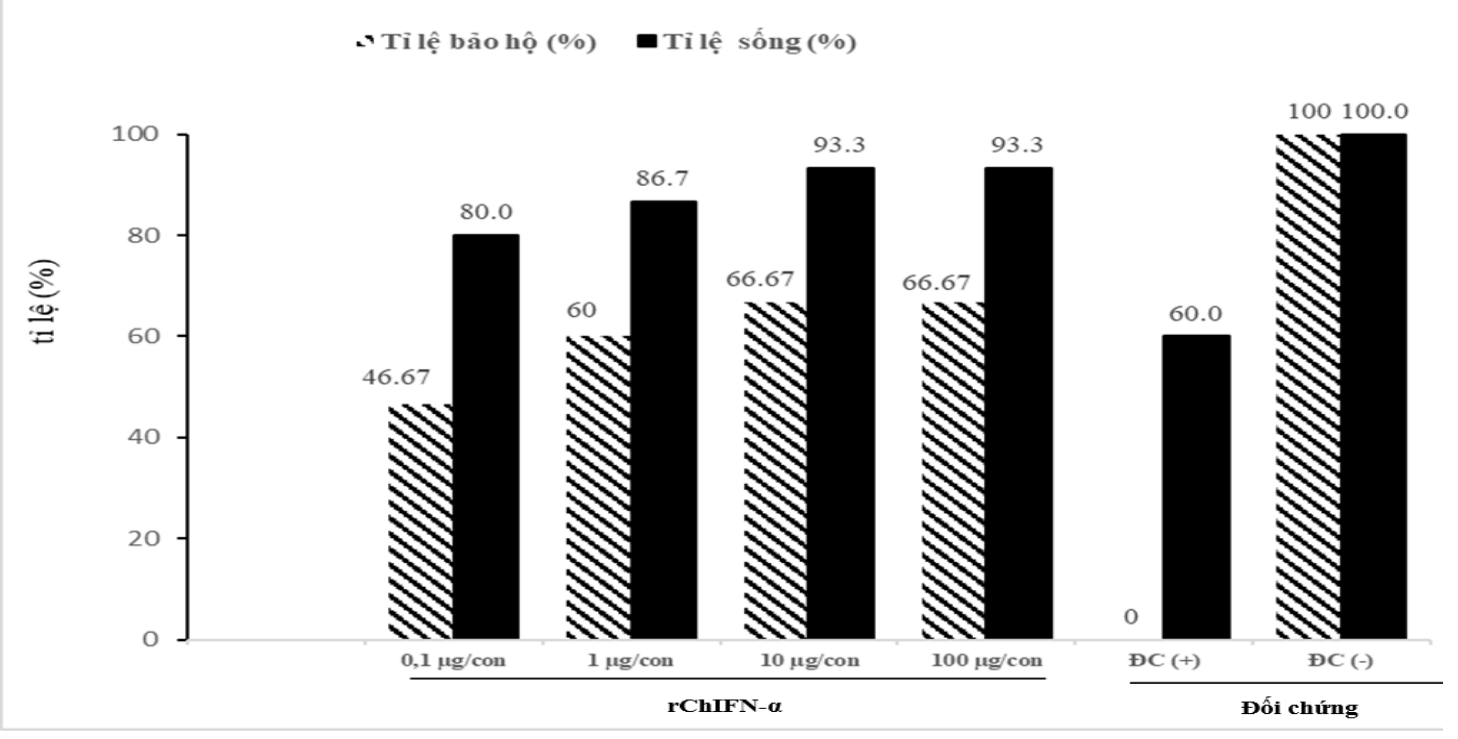

Hình 1. Hiệu quả kháng virus gây bệnh Gumboro của rChIFN- $\alpha$ 
Khả năng kháng của rChIFN- $\alpha$ thể hiện rõ ở tỉ lệ gà được bảo hộ và tỉ lệ gà sống. Kết quả cho thấy tỉ lệ gà bảo hộ ở các nhóm sử dụng rChIFN- $\alpha$ hàm lượng $0,1 \mu \mathrm{g}-100 \mu \mathrm{g} / \mathrm{con}$ dao động từ 46,67\% - 66,67\%, tương ứng (Hình 1). Trong khi đó, nhóm ĐC $(+)$, gà không được bảo hộ $(0 \%)$ và khác biệt có ý nghĩa so với các nhóm được điều trị $(\mathrm{P}=0,001)$. Tương tự, tỉ lệ gà sống ở các nhóm sử dụng rChIFN- $\alpha$ dao động 80 - 93,3\%, và cao hơn so với nhóm đối chứng ĐC (+) (60\%). Hai nhóm sử dụng $\mathrm{rChIFN- \alpha} 100 \mu \mathrm{g} / \mathrm{con}$ và $10 \mu \mathrm{g} / \mathrm{con}$, có tác dụng điều trị như nhau. Kết quả thí

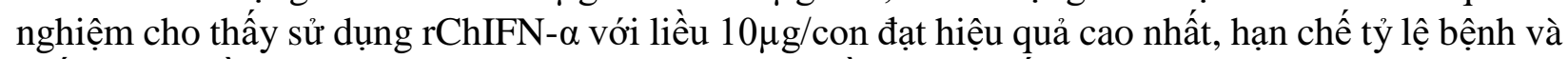
chết trong điều trị bệnh Gumboro hơn so với các liều khác. Kết quả này hoàn toàn phù hợp với nhận định của Marcus và cộng sự (1999), Hou và cộng sự (2011), Meng và cộng sự (2011).

Lí thuyết đã chứng minh ChIFN- $\alpha$ có hiệu quả trong điều trị bệnh Gumboro bằng cách cản trở sự tổng hợp RNA và protein của virus, giúp ngăn cản sự xâm nhiễm của virus vào tế bào mới. Trên thực tế, đã có nhiều nghiên cứu chứng minh ChIFN- $\alpha$ là tác nhân chống virus đầy tiềm năng, có hoạt tính cảm ứng promotor $\mathrm{Mx}$ cao (Schultz, Köck, Schlicht, \& Staeheli, 1995), và có tác dụng làm giảm tình trạng nhiễm virus Newcastle khi cho uống với liều cao (Marcus et al., 1999), có khả năng phòng và trị nhiều bệnh do virus khác trên gia cầm như bệnh cúm gia cầm do virus cúm H9N2 (Meng et al., 2011), virus gây bệnh viêm phế quản truyền nhiễm (Pei, Sekellick, Marcus, Choi, \& Collisson, 2001), ức chế sự tăng sinh khối u do Rous sarcoma virus (Plachý et al., 1999), có tác dụng phòng bệnh khá tốt đối với bệnh Gumboro và Newcastle trên gà thương phẩm (Mo, Cao, \& Lim, 2001).

\section{Tần suất biểu hiện bệnh trên gà thí nghiệm}

Trong thí nghiệm, có 78/180 gà thí nghiệm có các biểu hiện triệu chứng bệnh khi bị nhiễm virus Gumboro. Tần suất biểu hiện các triệu chứng được trình bày trong Bảng 3 .

\section{Bảng 3}

Các triệu chứng trên gà mắc bệnh

\begin{tabular}{|l|c|c|}
\hline \multirow{2}{*}{ Triệu chứng } & $\begin{array}{c}\text { Tần suất xuất hiện triệu chứng bệnh trên gà } \\
\text { thí nghiệm }\end{array}$ \\
\cline { 2 - 3 } & Số lưọng (con) & Tỷ lệ (\%) \\
\hline $\begin{array}{l}\text { Tiêu chảy phân trắng nhiều nước, hậu môn dính } \\
\text { đầy phân }\end{array}$ & 78 & 100,00 \\
\hline Gà ủ rũ, xù lông (nằm phủ phục) & 72 & 92,31 \\
\hline Da chân khô & 62 & 79,49 \\
\hline Gục đầu vào cánh & 35 & 44,87 \\
\hline Tự mổ vào hậu môn & 24 & 30,77 \\
\hline
\end{tabular}

Nguồn: Kết quả phân tích dữ liệu của nhóm nghiên cứu

\section{Tần suất xuất hiện bệnh tích trên gà chết}

Trong thí nghiệm, có 26/180 gà thí nghiệm chết, gà chết được mổ khám ghi nhận biểu hiện bệnh tích do virus Gumboro. Tần suất xuất hiện bệnh tích trên gà chết được trình bày trong Bảng 4. 


\section{Bảng 4}

Tần suất xuất hiện bệnh tích trên gà chết trong thí nghiệm $(\mathrm{n}=13)$

\begin{tabular}{|l|c|c|}
\hline \multirow{2}{*}{ Bệnh tích } & \multicolumn{2}{c|}{$\begin{array}{c}\text { Tần suất xuất hiện triệu chứng bệnh trên gà } \\
\text { thí nghiệm }\end{array}$} \\
\cline { 2 - 3 } & Số lưọng (con) & Tỷ lệ (\%) \\
\hline Túi Fabricius thay đổi (sưng, xuất huyết) & 26 & 100,00 \\
\hline Xuất huyết cơ đùi, cơ ngực & 26 & 100,00 \\
\hline Xuất huyết giữa dạ dày cơ và dạ dày tuyến & 24 & 92,31 \\
\hline Thận sưng & 18 & 69,23 \\
\hline Tuyến ức có điểm hoặc mảng xuất huyết & 12 & 46,15 \\
\hline
\end{tabular}

Nguồn: Kết quả xử lý từ dữ liệu điều tra

Kết quả ghi tần suất xuất hiện bệnh và bệch tích cho thấy: gà trong thí nghiệm có nhiều biểu hiện triệu chứng bệnh do virus Gumboro gây ra. Gần như toàn bộ gà đều bị tiêu chảy phân trắng, hậu môn dính đầy phân và gà ủ rủ, nằm phủ phục. Các triệu chứng này hoàn toàn phù hợp với nhận định của tác giả Hồ Thị Việt Thu (2012) về triệu chứng gà bị bệnh Gumboro. Toàn bộ gà chết đều có biểu hiện bệch tích sưng, xuất huyết túi Fabricius và bệnh tích xuất huyết cơ đùi, cơ ngực (100\%). Biểu hiện bệch tích này giống với miêu tả của Le (2004), Mo và cộng sự (2011), Bui (2003). Ngoài ra, gà chết cũng có các biểu hiện bệnh tích xuất huyết giữa dạ dày cơ và dạ dày tuyến, thận sưng và tuyến ức cũng có mảng xuất huyết. Các kết quả này cho thấy gà có các biểu hiện triệu chứng và bệnh tích điển hình chủ yếu tập trung ở các cơ quan miễn dịch và hệ cơ.

\section{Hiệu giá kháng thể của gà trước và sau khi khi gây nhiễm virus Gumboro}

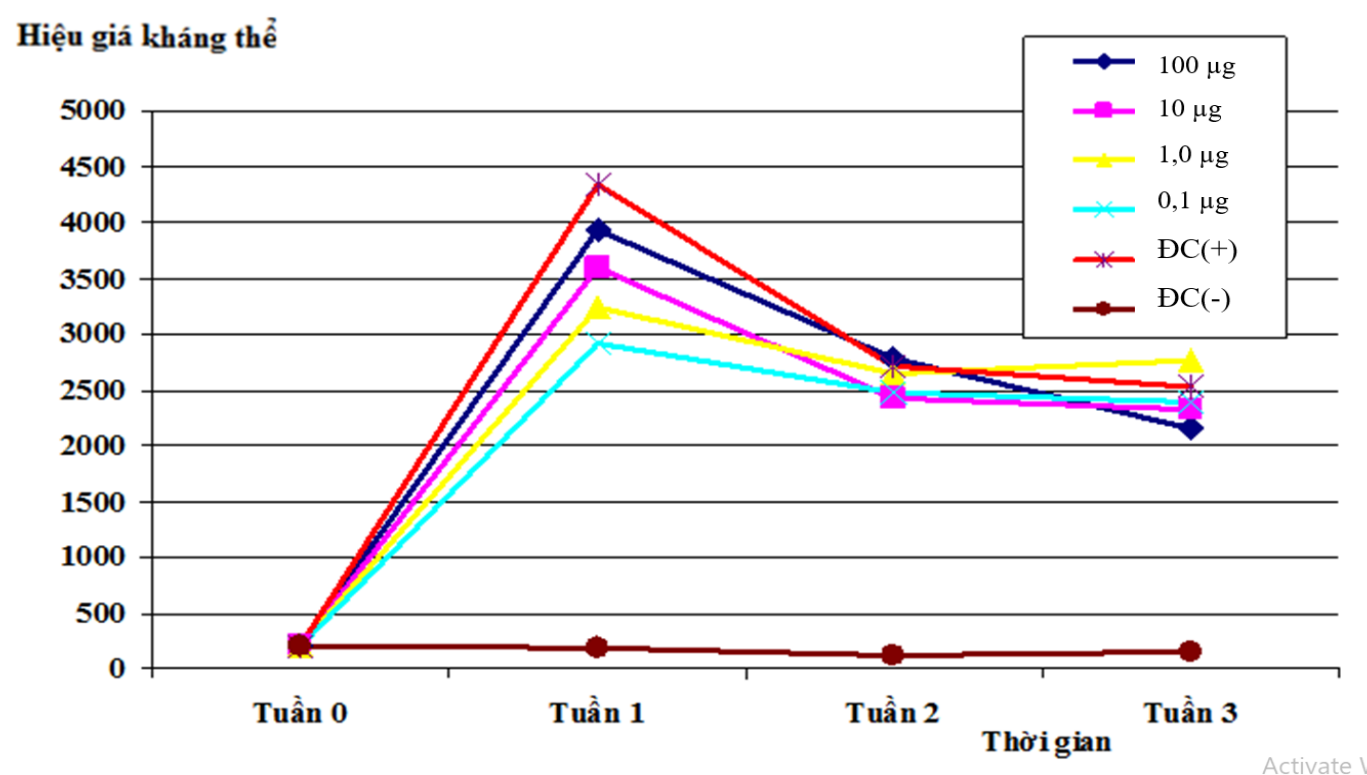

Hình 2. Biểu đồ kháng thể của gà trong thí nghiệm

Kết quả hiệu giá kháng thể của gà thí nghiệm (Hình 2) cho thấy: sau khi gà được gây nhiễm virus Gumboro, ĐC $(+), 100 \%$ gà đều có đám ứng miễn dịch với virus; trong khi đó nhóm đối 
chứng âm - gà không được gây nhiễm virus, hoàn toàn không có đáp ứng miễn dịch, hiệu giá kháng thể không tăng sau 3 tuần thử nghiệm.

Ở các nhóm có tiếp xúc với virus, kể cả đối chứng dương, hiệu giá kháng thể tăng mạnh sau 1 tuần gây nhiễm với virus Gumboro, lượng kháng thể của gà tăng nhanh và đạt đỉnh; tiếp đó lượng kháng thể bắt đầu giảm ở tuần thứ 2 và thứ 3 nhưng vẫn cao. Đối với các nhóm xử lí với rChIFN- $\alpha$, nhóm sử dụng rChIFN- $\alpha$ hàm lượng cao thì kháng thể tạo ra cao hơn nhóm sử dụng rChIFN- $\alpha$ hàm lượng thấp, và thấp hơn của $Đ C(+)$. Khi xử lý thống kê, lượng kháng thể của các

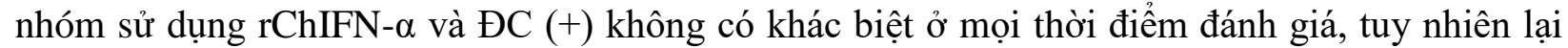
khác biệt có ý nghĩa so với ĐC (-). Điều này cho thấy, khả năng kháng virus của rChIFN- $\alpha$ hoàn toàn không gây ảnh hưởng đến khả năng đáp ứng miễn dịch của gà khi nhiễm virus. Do vậy, rChIFN- $\alpha$ có thể mang đến triển vọng sử dụng như một tá dược trong vaccine, giúp động vật có sự bảo hộ nhanh trước khi có miễn dịch lâu dài do vaccine.

\section{Kết luận và đề nghị}

Nghiên cứu bước đầu cho thấy, khi gà đã nhiễm virus, sử dụng rChIFN- $\alpha$ điều trị thì tỉ lệ bảo hộ dao động 46,67\% - 67,67\% và tỉ lệ gà sống đạt 80,0\% - 93,33\% tùy thuộc liều sử dụng. rChIFN- $\alpha$ khi sử dụng liều $10 \mu \mathrm{g} / \mathrm{con}$ tỉ lệ bảo hộ hơn $83 \%$, tỉ lệ sống hơn $90 \%$ và không gây ảnh

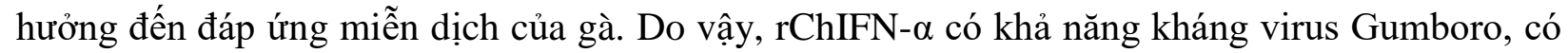
thể sử dụng điều trị bệnh Gumboro. Triển vọng tương lai, khi có dịch bệnh xảy xa, rChIFN- $\alpha$ sẽ là tác nhân tích cực giúp điều trị và khu trú ổ dịch. Tuy nhiên cũng rất cần thiết phải thực hiện nhiều nghiên cứu với quy mô lớn trên nhiều loại virus gây bệnh gia cầm.

\section{LỜI CẢM ƠN}

PGS.TS Hồ Thị Việt Thu, ThS. Trần Khánh Long đã tận tình hỗ trợ nhóm nghiên cứu.

\section{Tài liệu tham khảo}

Bui, L. D. (2003). Nuôi gà thịt (Broiler) công nghiệp và lông màu thả vưòn năng suất cao [Industrial broiler and backyard color feathering free ranger has high yield]. Hanoi, Vietnam: NXB Nông nghiệp Hà Nội.

Dey, S., Pathak, D. C., Ramamurthy, N., Maity, H. K., \& Chellappa, M. M. (2019). Infectious bursal disease virus in chickens: Prevalence, impact, and management strategies. Veterinary Medicine: Research and Reports, 10, 85-97. doi:10.2147/VMRR.S185159

Ghosalkar, A., Sahai, V., \& Srivastava, A. (2008). Secretory expression of interferon-alpha $2 b$ in recombinant Pichia pastoris using three different secretion signals. Protein Expression and Purification, 60(2), 103-109. doi:10.1016/j.pep.2008.02.006

Graaf, A., Ulrich, R., Maksimov, P., Scheibner, D., Koethe, S., Abdelwhab, E. M., ...Harder, T. (2018). A viral race for primacy: Co-infection of a natural pair of low and highly pathogenic H7N7 avian influenza viruses in chickens and embryonated chicken eggs. Emerging Microbes \& Infections, 7(1), 1-12. doi:10.1038/s41426-018-0204-0

Hou, F., Liu, K., Shen, T., Zhou, B., Cao, R., Li, P., \& Chen, P. (2011). Antiviral activity of rChIFN- $\alpha$ against vesicular stomatitis virus and Newcastle disease virus: A novel recombinant chicken interferon- $\alpha$ showed high antiviral activity. Research in Veterinary Science, 91(3), 73-79. doi:10.1016/j.rvsc.2010.11.015 
Iglesias-Figueroa, B., Valdiviezo-Godina, N., Siqueiros-Cendón, T., Sinagawa-García, S., Arévalo-Gallegos, S., \& Rascón-Cruz, Q. (2016). High-level expression of recombinant bovine lactoferrin in pichia pastoris with antimicrobial activity. International Journal of Molecular Sciences, 17(6), 902. doi:10.3390/ijms17060902

Le, N. V. (2004). Bệnh Gumboro ở gà và biện pháp phòng trị [Gumboro disease in chickens and preventive measures]. Hanoi, Vietnam: NXB Nông Nghiệp Hà Nội.

Li, S., De-gang, Z., Yong-jun, W., \& Yi, L. (2008). Transient expression of chicken alpha interferon gene in lettuce. Journal of Zhejiang University-Science B, 9(5), 351-355. doi:10.1631/jzus.B0710596

Macauley-Patrick, S., Fazenda, M. L., McNeil, B., \& Harvey, L. M. (2005). Heterologous protein production using the Pichia pastoris expression system. Yeast, 22(4), 249-270. doi:10.1002/yea.1208

Marcus, P. I., Heide, L. V. D., \& Sekellick, M. J. (1999). Interferon action on avian viruses. I. Oral administration of chicken interferon-alpha ameliorates Newcastle disease. Journal of Interferon \& Cytokine Research, 19(8), 881-885. doi:10.1089/107999099313406

Meng, S., Yang, L., Xu, C., Qin, Z., Xu, H., Wang, Y., ...Liu, W. (2011). Recombinant chicken interferon- $\alpha$ inhibits H9N2 avian influenza virus replication in vivo by oral administration. Journal of Interferon \& Cytokine Research,31(7), 533-538. doi:10.1089/jir.2010.0123

Mo, C. W., Cao, Y. C., \& Lim, B. L. (2001). The in vivo and in vitro effects of chicken interferon $\alpha$ on infectious bursal disease virus and Newcastle disease virus infection. Avian Diseases, 45, 389-399.

Pei, J., Sekellick, M. J., Marcus, P. I., Choi, I. S., \& Collisson, E. W. (2001). Chicken interferon type I inhibits infectious bronchitis virus replication and associated respiratory illness. Journal of Interferon \& Cytokine Research,21(12), 1071-1077. doi:10.1089/107999001317205204

Pham, L. S., \& Nguyen, T. (2004). Một số bệnh mới do virus ở gia súc, gia cầm nhập nội và biện pháp phòng trị [New diseases caused by virus in imported cattle and poultry and preventive measures]. Hanoi, Vietnam: NXB NN Hà Nội.

Plachý, J., Weining, K. C., Kremmer, E., Puehler, F., Hala, K., Kaspers, B., \& Staeheli, P. (1999). Protective effects of type I and type II interferons toward Rous sarcoma virus-induced tumors in chickens. Virology, 256(1), 85-91. doi:10.1006/viro.1999.9602

Reed, L. J., \& Muench, H. (1938). A simple method for estimating fifty percent endpoints. American Journal of Epidemiology, 27(3), 493-497. doi:10.1093/oxfordjournals.aje.a118408

Sams, L., Amara, S., Chakroun, A., Coudre, S., Paume, J., Giallo, J., \& Carrière, F. (2017). Constitutive expression of human gastric lipase in Pichia pastoris and site-directed mutagenesis of key lid-stabilizing residues. Biochimica et BiophysicaActa (BBA)-Molecular and Cell Biology of Lipids, 1862(10), 1025-1034. doi:10.1016/j.bbalip.2017.07.002

Schultz, U., Köck, J., Schlicht, H. J., \& Staeheli, P. (1995). Recombinant duck interferon: A new reagent for studying the mode of interferon action against hepatitis B virus. Virology, 212(2), 641-649. doi:10.1006/viro.1995.1522 
Teshome, M., Fentahunand, T., \& Admassu, B. (2015). Infectious bursal disease (Gumboro disease) in Chickens. British Journal of Poultry Sciences, 4(1), 22-28. doi:10.5829/idosi.bjps.2015.4.1.95172

Tizard, I. R. (2004). Cytokines and the immune system. Veterinary immunology - An introduction (7thed.). New York, NY: Elsevier.

Vo, T. T. M., Nguyen, G. T. T., Nguyen, Q. D., \& Nguyen, B. Q. (2014). Tạo dòng, biểu hiện và xác định hoạt tính sinh học của interferon gà tái tổ hợp thu nhận từ hệ thống nấm men Pichia pastoris [Cloning, expression and bioactivity determination of recombinant chicken interferon obtained from the Pichia pastoris yeast system]. Tạp chí Sinh hoc, 36(1), 216-225.

Wang, N., Wang, K. Y., Li, G., Guo, W., \& Liu, D. (2015). Expression and characterization of camel chymosin in Pichia pastoris. Protein Expression and Purification, 111, 75-81. doi:10.1016/j.pep.2015.03.012

Yu, R., Dong, S., Zhu, Y., Jin, H., Gao, M., Duan, Z., ...Li, Z. (2010). Effective and stable porcine interferon- $\alpha$ production by Pichia pastoris fed-batch cultivation with multi-variables clustering and analysis. Bioprocess and Biosystems Engineering, 33(4), 473-483.

Zhang, W., Inan, M., \& Meagher, M. M. (2000). Fermentation strategies for recombinant protein expression in the methylotrophic yeast Pichia pastoris. Biotechnology and Bioprocess Engineering, 5(4), 275-287. 